\title{
Non-lymphomatous malignancies associated with Human Immunodeficiency Virus infected patients
}

\author{
L. Jaichand Singh ${ }^{*}$, N. Biplab Singh ${ }^{*}$, S. Bhagyabati Devi ${ }^{f}$
}

\begin{abstract}
Abstrak
Keganasan non limfomatosa dapat terjadi pada pasien-pasien imunokompromais. Namun, penelitian rinci tentang kasus-kasus tersebut sangat kurang. Dalam tulisan ini diuraikan 4 kasus tumor padat para pasien HIV seropositif. (Med J Indones 2004; 13: 171-2)
\end{abstract}

\begin{abstract}
Keywords: solid tumours, HIV infection, radiation therapy, chemotherapy
\end{abstract}

Non lymphomatous malignancies may also develop in immunocompromised patients. However a detail study about the cases is lacking. Here we describe four cases of solid tumours in HIV seropositive patients. (Med J Indones 2004; 13: 171-2)

\section{CASE REPORTS}

Case 1: A 24 years old male patient with history of intravenous drug use (IVDU) for a period of 8 years developed bilateral upper cervical adenopathy. Nasopharynx showed an infiltrating mass involving the roof and posterior wall. The histopathological report of the mass was moderately differentiated squamous cell carcinoma. X-ray base of skull showed left petrous bone erosion. He was tested positive for HIV antibody, however he did not have any features of AIDS complex. He was incompletely treated by tele cobalt therapy upto a midline dose of 3000 cGy/15 exposures, he left the treatment. He has been resumed death.

\footnotetext{
* Department of Radiotherapy, Regional Institute of Medical Sciences, Imphal, Manipur, India

${ }^{f}$ Regional Institute of Medical Sciences, Imphal, Manipur, India
}

Case 2 : A 35 year old male developed a swelling over the right lower alveolus and floor of mouth for 1 year duration. He gives history of IVDU for 10 years and was tested positive for HIV antibody. Radiological survey of bones did not show any lytic lesion. The cytological report of the swelling was Plasmacytoma. He was treated by 3 cycles of VAD chemotherapy (vincristine $0.4 \mathrm{mg}$, adriamycin $15 \mathrm{mg}$ and tab. dexamethasone $120 \mathrm{mg}$ for 1-5 day given four weekly) with 50\% regression anterior to External Radiation Therapy (RT). A midline dose of 5000 cGy/25 exposures by tele cobalt therapy was given to face and neck with complete regression. However he developed severe radiation induced mucositis of grade III. He received two more cycles of VAD chemotherapy with very poor tolerance to chemotherapy. Soon he developed features of AIDS complex and expired from it.

Case 3 : A 25 year old male with history of IVDU 5 years back developed epistaxis and cervical adenopathy. Nasopharynx showed a friable mass over the roof and anterior wall of Nasopharynx. The pathological report was undifferentiated nasopharyngeal carcinoma. He was found positive of HIV antibody. $\mathrm{He}$ was given one cycle of anterior chemotherapy consisting of Inj. Carboplatin $450 \mathrm{mg}$ and 5 F.U. $1000 \mathrm{mgm}$ with poor tolerance to chemotherapy and with poor response. He was then given external RT to 
face and neck upto a midline dose of $7000 \mathrm{~Gy} / 35$ exposures with shrinking field technique by tele cobalt therapy with poor tolerance to radiation, developing grade III radiation induced mucositis. After the completion of radiation he developed features of AIDS complex and expired soon from it.

Case 4 : A 35 year old male with history of IVDU developed odynophagia and right cervical adenopathy for 2 months duration. The indirect laryngoscopic examination revealed a proliferative mass over the right pyriform fossa involving the epiglottis. The vocal cords were mobile and free. He was tested positive for HIV antibody. The pathological report was moderately differentiated squamous cell carcinoma. He was given external RT by tele cobalt therapy upto a midline dose of $7000 \mathrm{cGy} / 35$ exposure. He developed opportunistic infection during the RT and his tolerance to RT was poor developing radiation induced mucositis of grade III. He is still surviving 6 months after treatment.

\section{DISCUSSION}

K.S. and NHL are the two common HIV associated malignancies. Besides these two types many other malignancies have also been reported. Bronchogenic carcinoma, Gastrointestinal malignancies, Genito urinary malignancies, myelomas are some of the malignancies reported. However with the active anti retroviral therapy the mortality of HIV infected patients have declined in the developed countries and so also the incidence of HIV related malignancies specially NHL and KS. Other non - AIDS defining tumours such as Hodgkin Lymphoma, carcinoma of skin and lip, lung cancers are being reported recently in several cohort studies with increased frequency in HIV infected patients. ${ }^{1,2,3,5}$ These cancer appear in a relatively younger age group and gehaves aggressively.

A retrospective study of lung cancers in HIV infected patients showed the disease to be occurring in relatively young patients, appearing earlier in the course of HIV infections. ${ }^{2}$ About $50 \%$ were asymptomatic for HIV infection at the time of diagnosis of lung cancer despite a low $\mathrm{CD}_{4}$ count. The median overall survival was significantly short, majority of them succumbing to the lung cancer.
The impact of HAART (highly active antiretroviral therapy) in the management of advanced and aggressive malignancies associated with HIV infection needs further clinical studies. ${ }^{6}$ The natural history of cancer in patients with HIV infection differs from that of general population. Unusual aspects of tumour localization, growth behaviours, and therapeutical response distinguish tumours in patients with HIV infection from those without. The management of such malignancies is still not well defined.

In HIV related NHL use of colony stimulating factor and antiretroviral drugs along with anticancer drugs have shown some encouraging results but it needs further study. Regarding the nonlymphomatous malignancies such a study has not been reported. ${ }^{7}$

Though much has been known about HIV/AIDS, very little progress had been made regarding the optimal therapy about the HIV associated non lymphomatous malignancies.

\section{REFERENCES}

1. Ree HJ, Strauchen JA, Khan AA, Gold JE, Crowley JP, Kahn H, et al. Human Immunodeficiency Virus associated Hodgkin's Disease. Cancer 1991; 67:1614-21.

2. Tirelli U, Spina M, Sandri S, Serraino D, Gobitti C, Fasan $\mathrm{M}$, et al. Lung carcinoma in 36 patients with Human Immunodeficiency virus infection. Cancer 2000; 88:536-9.

3. Romito A, Grizzuti MA, Tucci M, Silvestris F. Malignant neoplasm and AIDS. Review of the literature and critical considerations on a case of epidermoid carcinoma of the anus. Recenti Prog Med 1997; 88:348-55.

4. Waddell KM, Lewallen S, Lucas SB, Atenyi - Agaba C, Herrington CS, Lomba G. Carcinoma of the conjunctiva and HIV infection in Uganda and Malawi : $\mathrm{Br} \mathrm{J}$ Opthlamol 1996; 80:502-8.

5. Maclean H, Dhillon B, Ironside J. Squamous cell carcinoma of the eyelid and the acquired immunodeficiency syndrome. Am J Ophthalmol 1996; 121:219-21.

6. Molina A, Krishnan AY, Nademanee A, Zabner R, Sniecinski I, Zaia J, et al. High Dose Therapy and Autologous Stem cell transplantation for human immunodeficiency virus associated Non-Hodgkin Lymphoma in the area of highly active antiretroviral therapy. Cancer 2000; 89:680-9.

7. Newell M, Goldstein D, Milliken S, Lewis C, Hoy J, Thombon B, et al. Phase I/II trial of filgastim, CEOP chemotherapy and antiretroviral therapy in HIV-related non-hodgkin's lymphoma. Ann Oncol 1996; 7:1029-36. 